\title{
Construction Contractors Involvement in Disaster Management Planning
}

Peter Stringfellow, (Queensland University of Technology, Australia)

\begin{abstract}
Disasters, both natural and man-made, cause major damage and loss of life. Because of this, governments around the world are looking at building resilience to ensure communities can recover quickly and have minimal impact from a disaster. Part of building resilience is to plan for disaster management and recovery. Literature reveals that construction contractors can play a critical role within this process as they have control of resource supply chains and key knowledge and skills they are well suited to assist in disaster planning. However, as literature also reveals there is currently little involvement of construction contractors in the disaster planning process. This gap between what should be done and what is currently done is investigated. Representatives from industry bodies are interviewed to determine their understanding of the industry's involvement in disaster planning and what capacity the industry might have to be involved. The interviewee's responses agree with current literature that there is currently little or no involvement with disaster planning however there is interest in being involved with disaster management if there was a forum for this to occur. Based on the responses the researcher has proposed a model to engage construction contractors within state government disaster management planning.
\end{abstract}

Keywords: Construction contractor, Disaster, Disaster planning, Reconstruction resources, Disaster management

\section{Introduction}

Disasters, both natural and man-made cause major damage and lose of life. In 2011 natural disasters alone killed over 30,000 people and caused economic damage of \$US 366 billion (Centre for Research on the Epidemiology of Disasters, 2012). Each year on a global scale 250 million people are exposed to natural disasters (World Economic Forum, 2011). Despite Australia having a comparatively lower rate of disasters (Centre for Research on the Epidemiology of Disasters, 2012), the 2011 floods in Queensland are estimated to have cost $\$ 10.8$ billion in damages and losses (Queensland Government, 2011b). These figures are alarming and with communities and cities being built closer together the impact of disaster is only going to increase (Wang, 2012).

Compared to a standard project, rebuilding after a disaster is chaotic, complex, uncertain and changing (Chang, Wilkinson, Brunsdon, Seville, \& Potangaroa, 2011; Chang, Wilkinson, Potangaroa, \& Seville, 2012; Le Masurier, Rotimi, \& Wilkinson, 2006). Due to the nature of these projects they often lack strategy and fail to respond effectively to the needs of the affected community (Sadiqi "Wardak", Coffey, \& Trigunarsyah, 2012). A Construction contractor can add considerable value and provide assistance to disaster management and recovery in a number of areas, such as sourcing resources, procurement, project management and logistical planning (Chang, et al., 2011). Despite these benefits of construction contractors' involvement with a reconstruction project, the industry as a whole has had little involvement with disaster reconstruction projects being unable and unprepared to assist should a disaster occur (Bosher, Carrillo, Dainty, Glass, \& Price, 2007; Chang, et al., 2011). Chang, et al. (2011) goes on to say that the construction industry is not prepared for post-disaster construction and the involvement in post-disaster management is poor. In 
general 'the construction industry has not been sufficiently involved with emergency management to date' (Bosher, et al., 2007, p. 243).

Resources such as labour, materials and equipment are important for any reconstruction project but are crucial for a reconstruction project post disaster (Queensland Government, 2011b; World Economic Forum, 2012). Construction contractors working in an area have contacts with suppliers and existing supply chains (World Economic Forum, 2012) therefore making them well suited to assisting with resource planning in disaster management planning. As construction contractors are involved with the construction of infrastructure it makes sense that they should also be involved in the event that the infrastructure is destroyed by a disaster event (Siriwardena, Malalgoda, Thayaparan, Amaratunga, \& Keraminiyage, 2013).

With a focus on building resilience for disaster management (Queensland Government, 2011a; World Economic Forum, 2012) there needs to be an ability for the Australian construction contractors to be able to assist immediately after a disaster in the resource management in a post disaster reconstruction project. The issues addressed in this research is the role construction contractors at various stages of the disaster reconstruction and particularly in what ways they can be involved with disaster resource planning. The study is limited to members of professional bodies representing construction contractors. The variables are therefore the persons and their specific involvement in disaster management planning.

\section{Stages of Disaster Reconstruction}

Disaster management is defined as 'The coordinated efforts and processes to effect the immediate, medium and long term holistic regeneration of a community following a disaster' (Norman, 2006, p. 16). There are three main stages identified in Disaster management, firstly the planning or preparation stage, secondly the immediate response or relief stage and then the long term response and recovery phase (Lloyd-Jones, 2006; Town Planning and Urban Design Collaborative, 2011; World Economic Forum, 2012). The relationship between these is shown in figure 1. Lloyd-Jones (2006) proposes a fourth phase called the transition phase. He describe that this phase is because following the immediate response and relief stage there is usually a gap before the longer-term recovery starts.

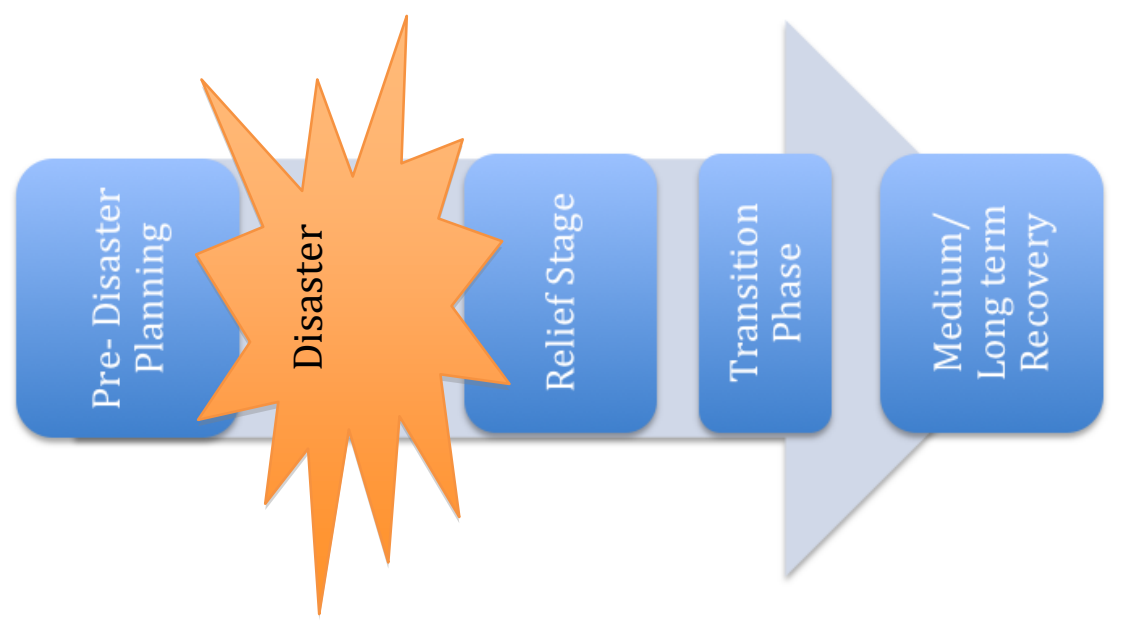

Figure 1 Stages of Disaster Recovery (Lloyd-Jones, 2006)

Stringfellow, P (2014) 'Construction contractors involvement in disaster management planning', Australasian Journal of Construction Economics and Building, 14 (2) 120-132 
Within each of these stages a construction contractor can have varying roles and a number of critical activities (Siriwardena, et al., 2013), these have been identified and are listed below.

\section{Pre-Disaster Planning}

Within the pre-disaster planning phase a construction contractor can be involved with upgrading skills and incorporating disaster prevention into construction work (Chang, et al., 2011). This stage should allow all stakeholders including construction contractors to be involved in emergency management planning (Bosher, et al., 2007; University of Oregon Partnership for Disaster Resilience, 2007). The University of Oregon's Partnership for disaster resilience (2007) outline a number of strategies that can be developed during this time. These include; disaster recovery plans, temporary housing plans, reconstruction plans and guiding principles for reconstruction.

\section{Immediate Relief}

Although this stage is usually filled with government and non-government organisations, construction contractors can still play a role in this area. 'A construction company already operating in the affected area is well placed to contribute labour, materials and equipment, as well as mobilizing networks and supply chains that can save lives and reduce suffering' (Hindustan Construction Company, n.d.). As part of Hindustan Construction Company's (HCC) Corporate Stewardship policy the Indian construction company train certain staff in disaster management so that should a disaster occur near where HCC is working they are able to respond in relief work.

\section{Long Term Recovery}

In the long term a construction contractor will be able to complete the actual rebuilding work of housing and infrastructure. There are a number of skills and services that a contractor is able to provide during this phase which include planning and program management, damage and hazard assessment and providing advice on critical infrastructure (World Economic Forum, 2012). The World Economic Forum proposes modes of delivery for its Disaster Resource Partnerships however all of the proposed models are based on a construction contractor being engaged post a disaster has occurred (World Economic Forum, 2012).

The effectiveness of any relief or recovery work is dependent on the planning that has been carried out previously (Rotimi, Wilkinson, \& Myburgh, 2011). If 'getting organized and identifying critical issues... is the first step in the development of a long-term recovery plan' (University of Oregon - Partnership for Disaster Resilience, 2007, p. 4) construction contractors should be involved within this process to ensure that long term reconstruction efforts are able to be implemented efficiently.

\section{Construction Contractors and Availability of Resources}

A post-disaster reconstruction project is more likely to face problems, compared to a standard construction project. One of these problems stems from resource shortages with supply markets in disorder following a disaster (Chang, Wilkinson, Potangaroa, \& Seville, 2010, September; Chang, Wilkinson, Seville, \& Potangaroa, 2012; Yan, Wilkinson, Potangaroa, \& Seville, 2011). Despite the types of resources required for a post disaster reconstruction project being the same as for any other construction project; materials, labour, equipment and expertise, following a disaster there is often a large demand for materials with little supply available as well as labour shortages to contend with (Chang, Wilkinson, Seville, \& Regan, 2010).

A study by Yan, et al. (2011) concluded that the factors affecting resource availability could be split into three areas:

Stringfellow, P (2014) 'Construction contractors involvement in disaster management planning', Australasian Journal of Construction Economics and Building, 14 (2) 120-132 
- Project related factors

- Contractor related factors and

- External factors

This research however is limited in its finding as it focused only on the Wenchuan earthquake in China and its reconstruction efforts. A similar study conducted by Chang, et al. (2012) looked at the factors affecting resource availability in disaster relief projects in China, Indonesia and Australia. Figure 2 shows a summary of the findings.
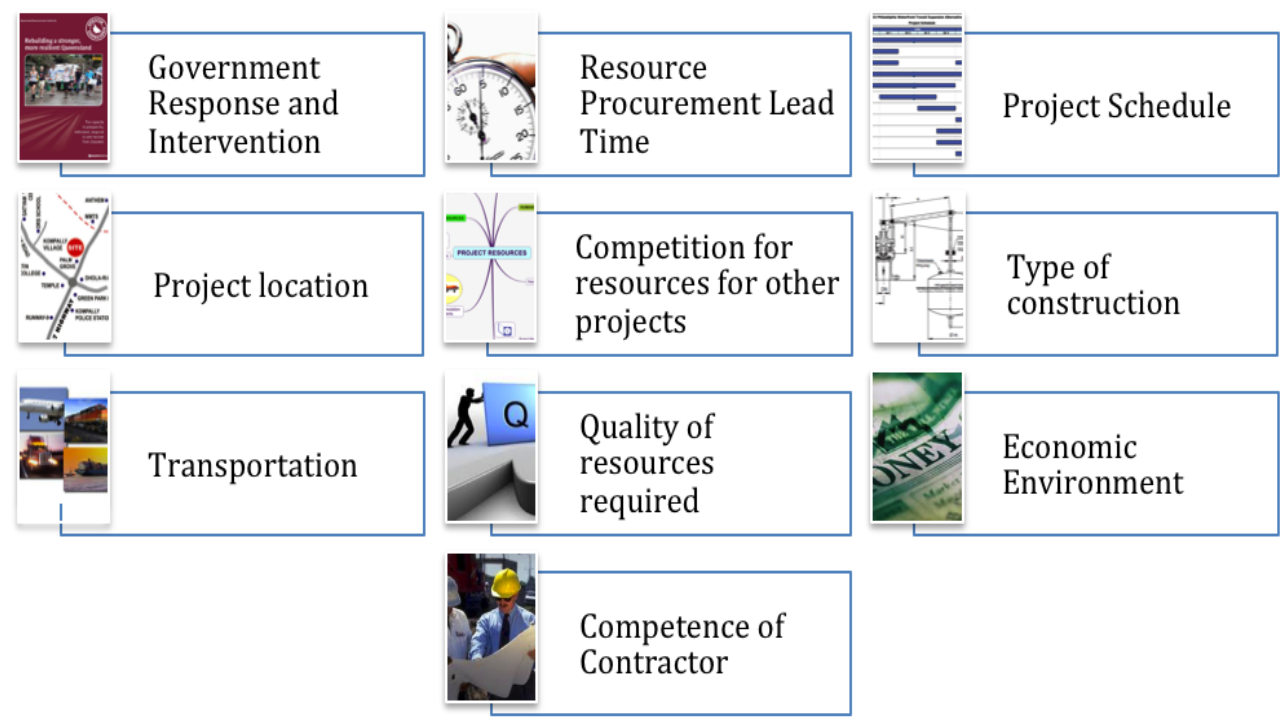

Figure 2 Factors affecting resourcing in a post disaster project (Chang, et al. 2012, p.564)

Within all three case studies the competence of the construction contractor was identified as a common issue. The World Economic Forum (2012) supports this and reports that a construction company working in an area affected by a disaster is best suited to contribute labour, materials and equipment to assist in rebuilding in the affected area. Construction contracts engaged in reconstruction work can benefit from having resourcing strategies and plans for disaster reconstruction (Chang, et al., 2010, September).

\section{Construction Industry Capability and Capacity}

There is international action through the United Nations, International Strategy for Disaster Reduction for reducing impact of disaster. One challenge identified is the preparedness of the stakeholders involved. The action strategy to overcome this challenge is to 'strengthen disaster preparedness for effective response at all levels' (United Nations Office for Disaster Risk Reduction (UNISDR), 2007). Despite this focus, involving construction contractors into emergency management planning have been largely neglected (Bosher, et al., 2007). Thus many construction companies do not have plans or strategies for post disaster reconstruction (Chang, et al., 2011). Bosher, et al., (2007) reports there are two main barriers preventing the construction industry from being involved with disaster planning. The first is that the construction industry does what needs to be done to meet requirements while maximizing their profits. The second barrier is unless the government imposes initiatives or rewards performance (Lorch, 2005), disaster management remains outside the realm of construction contractors. Concurrent to this is the fact that disaster managers have not been proactive in utilizing the knowledge and skills of the construction industry (Bosher, et al., 2007). Although the benefits to society and affected communities of disasters are clear there are other benefits to construction contractors. As well as, having a legislative framework to 
strengthen the obligations of contractors to be involved with planning (Jim O'Sullivan \& The Consultancy Bureau Pty Ltd, 2009) there are a number of benefits to a construction contractor for involvement with disaster planning and management: it strengthens relationships with government and local organisations, reinforces brand reputation and company values and assists with staff development. As previously mentioned there are a number of barriers that prevent the construction industry as a whole but particularly a construction contractor being involved with disaster planning. However not having their involvement compromises the disaster plan and the level of preparedness for a disaster (Jim O'Sullivan \& The Consultancy Bureau Pty Ltd, 2009).

\section{QId Strategic Policy}

There are a number of stakeholders that need to be involved with disaster management; the communities affected, non-government organizations, planners, engineers and construction contractors and of course Government. The Australian Government recognizes the need for governments at all levels to be involved with developing and implementing disaster planning (Commonwealth of Australia, 2011). The Queensland (QLD) Government Disaster Management Group (2010) agrees with this need for stakeholder collaboration and has a framework for ensuring a 'resilient' approach to disaster management. The 8-part framework is shown in figure 3.

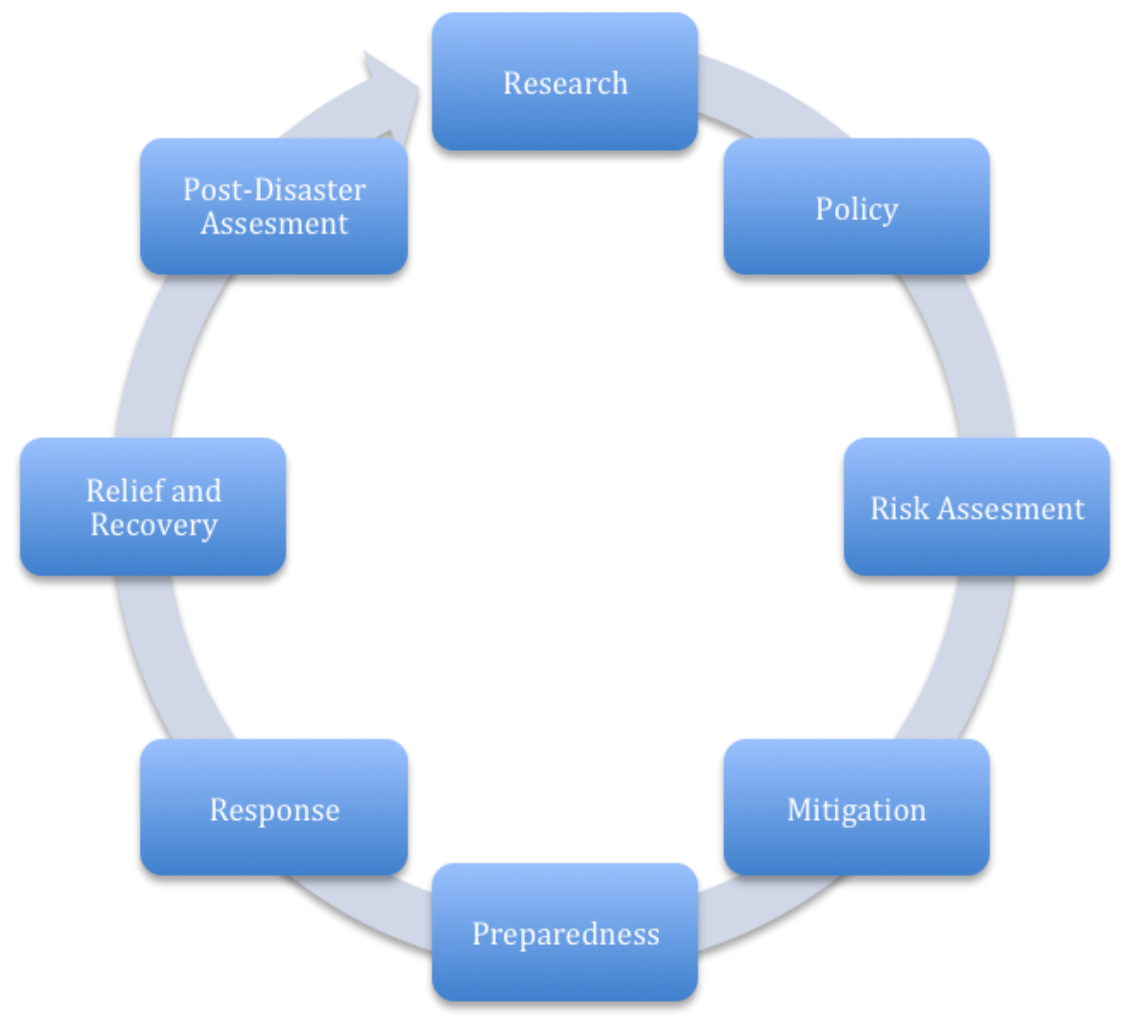

Figure 3 QLD Disaster Resilience Framework (Queensland State Disaster Management Group, 2010)

The QLD Government sees disaster preparedness driven by research and policy, assessment of the risk and possible ways of mitigation. There are two objectives in disaster preparedness, firstly to ensure everyone is prepared should a disaster occur and secondly to build capability and involvement of the stakeholders (Queensland State Disaster Management Group, 2010).

This framework approached by the QLD Government is similar to that found in literature. A further study on the previously mentioned Wenchuan earthquake in China, proposed an

Stringfellow, P (2014) 'Construction contractors involvement in disaster management planning', Australasian Journal of Construction Economics and Building, 14 (2) 120-132 
integrated planning framework, this involved a legislative framework to enable construction contractors to become involved in planning. This is shown in Figure 4. This framework also proposes that legislation and policy imposed on the construction industry will force the industry to build their capability and allow for resource planning. Governments themselves need to find ways to encourage involvement and engagement from industry (ChangRichards, Wilkinson, Potangaroa, \& Seville, 2013). Legislation needs to be revised and updated for disasters prior to a disaster to ensure there is no delay to reconstruction works and communities can be rebuilt efficiently (Rotimi, et al., 2011). The framework shown in figure 4 demonstrates the link between legislation and construction capability and how this entails resource planning as well as training and the creation of procurement inventories.

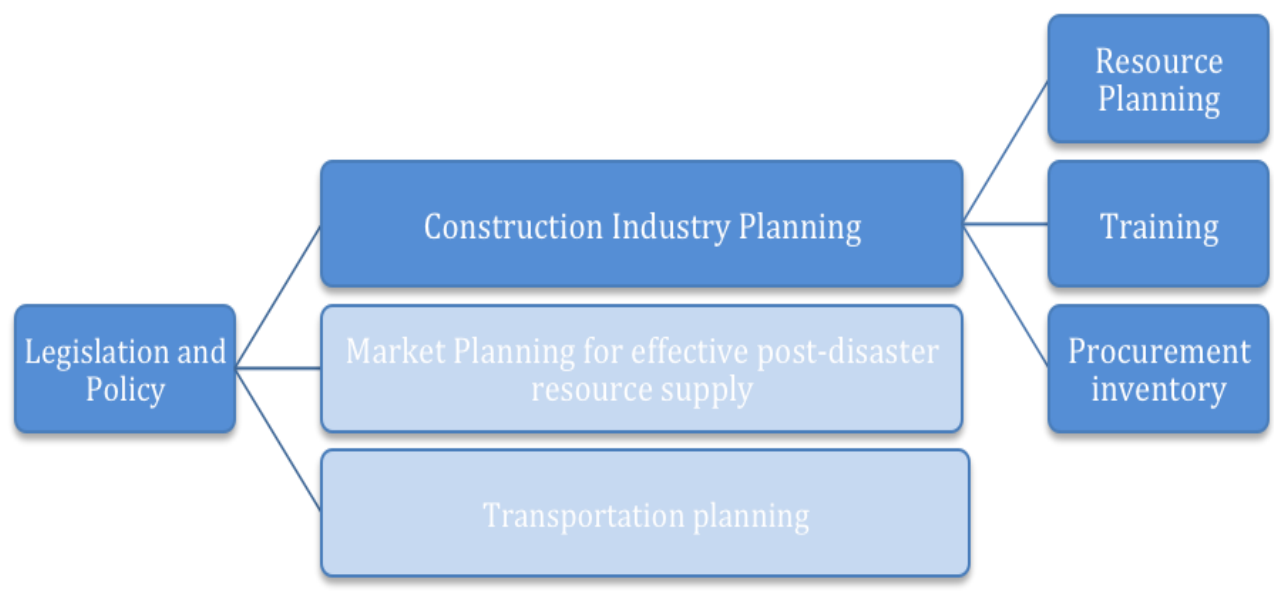

Figure 4 Integrated Planning Framework (adapted from Chang, et al., 2011)

\section{Research Methodology}

In order to archive a view on disaster management representative of the wider industry, interviews were conducted. Seven key representatives from five industry bodies were approached and interviewed individually either face to face or on telephone, to determine their views on the industries involvement with disaster management planning.

The Industry Bodies approached where the;

- Australian Institute of Building,

- Chartered Institute of Building,

- Royal Institute of Chartered Surveyors,

- Queensland Major Contractors Association, and

- Infrastructure association Queensland

At the end of June 2012 there were 950,000 persons working in the construction industry in Australia. Of that number $16.2 \%$ of 154,000 persons worked for construction contractors and Queensland has about $24.1 \%$ of this number making 37,114 persons (Australian Bureau of Statistics, 2012). The industry bodies represent approximately 5000 individual members and over 70 major construction contractors. A number of the organisations are international organisations drawing on expertise from an international context (Chartered Institute of Building, 2013; Construction in focus, 2013; Royal Institute of Chartered surveyors, 2013).

Each representative was asked to comment on the overall level of consultation between government departments and industry bodies. They were then asked questions relating to the consultation specifically in the previously mentioned QLD 2013 Flood recovery plan and questions relating to the framework proposed by Chang, et al in Figure 4. 


\section{Results \\ Industries General Involvement}

Before being able to look into areas of where construction contractors have the potential to assist in a disaster situation it is important to establish whether the experience of the industry matches the literature in regards to the current level of consolation between government agencies and construction contractors. Between the seven interviewees there was agreement that the construction industry as a whole has little or limited involvement in disaster planning.

'None' (Interviewee 1)

'Rating of 5 out of 10' (Interviewee 2)

'Planning Exercises have left out the Construction industry' (Interviewee 2)

Even those interviewees outside of Australia expressed the same view with regards to the industries involvement in their areas.

'Pre-Christchurch Earthquake the level of consultation was zero' (Interviewee 7)

A number of reasons where put forward as to the reasons for the current lack of consultation:

The nature of the construction industry is as a follower; it only follows where the money is and is not interested in strategic planning; Construction contractors don't have the time to assist in disaster management; There is sometimes a conflict or perceived conflict between governments and contractors.

These comments provide some insight and explanation as to the lack of involvement and agree with the previously presented literature. The current involvement involves no more than traditional design and construction activities for reconstruction work (R. Haigh, D. Amaratunga, \& Kerimanginaye, 2006). Thus when consultation is provided it seems to only be focused on providing a response not providing strategic advice to the planning of reconstruction work. It is a 'reactive' response rather than a 'strategic' one (Interviewee 6).

\section{Benefits (Perceived or Real)}

Although literature suggests that the construction industry can assist in disaster planning (Bosher, et al., 2007), there was disagreement amongst the interviewees as to how they could benefit or if there was a benefit.

'I see a case for better disaster planning but don't see contractors playing a role in it' (Interviewee 1)

Other interviewees saw benefits in construction contractor's involvement in disaster planning for the relief phase/stage of a disaster. Within this relief period the construction industry can provide machinery and labour as the industry already owns and has access to this equipment. The potential for construction contractors to be involved in the planning for longterm recovery phase was not as clear to the interviewees. However the need to be rebuilding communities quicker was recognised.

'How do we get a better handle once this (a disaster) has happened on the actual rebuilding process rather than just saving people, getting them to hospital and getting the roads and the services up.' (Interviewee 4)

One interviewee stating that tendering for post-disaster reconstruction projects does not work, due to the nature of the tendering process and the need to rebuild quickly. Having 
clear 'plans in place for rebuilding' will allow for the industry to be involved earlier and communities to rebuild quicker.

\section{Queensland Flood Recovery Plan}

In early 2011 and 2013 Queensland faced wide spread flooding, this flooding caused over $\$ 10.8$ billion of damage (Queensland Reconstruction Authority, 2013). Following the 2013 floods a 'Flood Recover Plan' was created to 'provide strategic guidance for the coordination and management of recovery, reconstruction ... activities undertaken by the Queensland State government, local governments, non-government partners, industry and not-for-profit organisations' (Queensland State Disaster Management Group, 2010). The plans purpose was to assist communities to recover quickly and ensuring that resources are employed effectively.

When asked about the level of consultation that occurred between industry and governments in the development of this plan the interviewees where not aware of any. This is also evident given the scope of the plan being to document the 'State's recovery governance framework' (Queensland Reconstruction Authority, 2013) and being limited to the areas affected by Tropical Cyclone Oswald and its subsequent rainfall and flooding.

During this disaster however, construction contractors and the industry as a whole called upon to assist in the clean-up and response phase of the construction. One interviewee recalled getting asked by the then, Lord Mayor of Brisbane, Campbell Newman, if the industry body could provide assistance in the immediate response to the 2011 Brisbane Floods. The construction industry was able to provide resources and equipment to assist in the clean-up. A number of contractors paid for this work personally.

'The need was obvious so the industry responded' (Interviewee 5)

This shows a willingness from the industry to be involved, this is in contrast to the current view that contractors only do what they do maximise profits (Bosher, et al., 2007). Many companies feel this sort of work helps to develop corporate social responsibility and maintains an image of being good corporate citizens (Petrovic-Lazarevic, 2008).

\section{Mechanism to Drive Involvement}

In the framework proposed by Chang, et al. (2011) the main mechanism driving the consultation is a change in legislation. Although often legislation changes occur after a disaster these are generally limited to speeding up planning processes. The interviewees expressed that they did not see that legislation to force contractors to be involved would achieve. Rather a voluntary basis was suggested as being a better way of driving consultation.

'How do you legislate for involvement? Willing participation is a much better approach' (Interviewee 5)

'There needs to be collective do gooding' (Interviewee 6)

Apart from the issue of how to form such legislation, Legislating involvement would cause an adversarial working environment between governments and contractors therefore not archiving positive results. Despite the overall sentiment that voluntary consultation is a better approach it was expressed by two interviewees that if the consultation was onerous it would be expected that 'Compensation for expenses be paid' (Interviewee 2) making sure the industry was not out of pocket for the services rendered.

All seven interviewees expressed that consultation through Industry bodies, such as those they represented, was a much better approach then to do this through individual companies. Such an approach allows 'work to be shared around' (Interviewee 5) and allows for a fair

Stringfellow, P (2014) 'Construction contractors involvement in disaster management planning', Australasian Journal of Construction Economics and Building, 14 (2) 120-132 
process and would save resources. However as raise by one interviewee: collaboration could still be difficult given the competitive nature of the industry and not necessarily a willingness to work together.

\section{Resourcing / Procurement Inventory}

Following a disaster resources shortages and increased costs in building materials are common due to the effected supply chain and the increased demand (Chang, Wilkinson, Seville, et al., 2012).

'Where do you source things when a disaster arises?' (Interviewee 4)

As previously stated a construction company working in an area affected by a disaster is best suited to contribute labour, materials and equipment to assist in rebuilding in the affected area (World Economic Forum, 2012). During pre-disaster planning governments could consult industry regarding the resource supply chains, equipment locations and contacts. Many interviewees suggested that a checklist for different types of disasters with communication chains to get equipment, materials and labour mobilised quickly in the event of emergency.

'All companies should have procurement inventories and know where things are at any given time' (Interviewee 5)

Governments could consult this checklist and work through contacting construction contractors who are known to have certain procurement items if these items are required. Four of the 7 Interviewees expressed a view that communication in times of disasters is an important aspect of coordinating. Having a checklist and procedure to follow of whom to contact and when, was proposed as a solution to getting the industry mobilised following a disaster. It was also suggested that formats such as workshops be held periodically between industry and governments to ensure the above mentioned checklists and procedures are up to date and the industry is ready to respond.

\section{Training}

Training is an important part of building the capacity of those involved in disaster management (Siriwardena, et al., 2013). One interviewee expressed that training for disasters was 'critical... so that everyone can go into remote control' and know what needs to happen when a disaster happens. Other interviewees expressed that construction contractors do well at what they do and don't need further training and most companies have training mechanism built into the company. Due to the multidisciplinary nature of disaster management, formal education means are usually ineffective (Siriwardena, et al., 2013) and lifelong learning is seen as a better way to address this issue.

\section{Conclusion}

Australia and the state of Queensland have faced many large-scale natural disasters in recent years. Previous research has revealed that although the construction industry is best placed to be involved with planning and management of disasters they have currently little involvement.

The aim of the research was to better understand the role that Australian construction contractors can play in disaster planning and hopes to understand the proposed framework for involvement in pre disaster planning. Ultimately the aim is to ensure that disaster reconstruction is more efficiently managed and Australia continues to become a resilient society. 
The study shows that the literature is correct in regards to the current level of consultation between governments and industry with regards to disaster management planning. Apart from contractors own internal planning there is little wider planning. During the study a number of questions were asked in relation to a proposed framework in figure 4 . The study demonstrated that the mechanism for driving involvement should not be through legislation but rather on a voluntary basis with financial compensation where required. The outcomes of the planning would involve resource planning involving workshops and a procurement register, as well as life-long training - as opposed to formalised training - and creation of communication plans. From the study a framework of consultation is proposed involving the above factors and shown in figure 5.

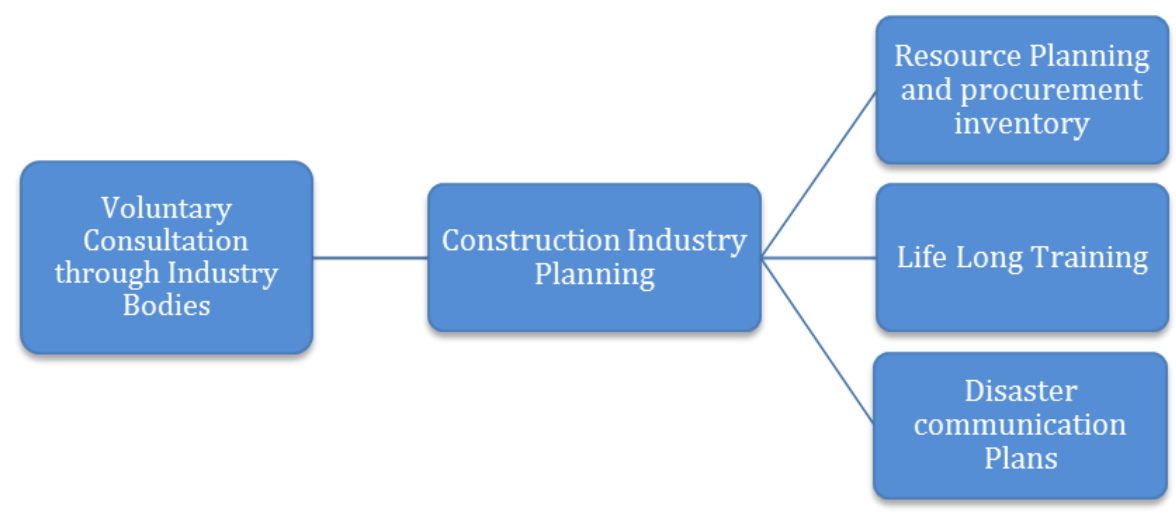

Figure 5 Construction Contractor (and wider industry) Planning Framework

It is recommended that further studies be conducted with wider sample groups of construction professionals and government agencies to gain a broader view of the solutions to construction contractors' involvement in disaster management planning. It is also recommended to investigate the proposed framework in a number of case studies to test its validity to be used as a means of contractor consultation.

\section{Acknowledgments}

I wish to thank for the support from the many industry bodies involved with this research.

\section{References}

Australian Bureau of Statistics (2012) Construction Industry. Retrieved 2013, September 23, from

http://www.abs.gov.au/ausstats/abs@.nsf/Latestproducts/8772.0Main\%20Features2201112? opendocument\&tabname $=$ Summary\&prodno $=8772$.0\&issue $=2011$ 12\&num $=\&$ view $=$

Bosher, L., Carrillo, P., Dainty, A., Glass, J., \& Price, A. (2007) Realising a resilient and sustainable built environment: towards a strategic agenda for the United Kingdom. Disasters, 31 (3), 236-255. Retrieved from http://dx.doi.org/10.1111/j.1467-7717.2007.01007.x doi:10.1111/j.1467-7717.2007.01007.x

Centre for Research on the Epidemiology of Disasters (2012) Annual Disaster Statistical Review 2011. Retrieved March 29, 2013, from http://www.cred.be/publication/annualdisaster-statistical-review-2011

Chang-Richards, Y., Wilkinson, S., Potangaroa, R., \& Seville, E. (2013) Resource challenges for housing reconstruction: A longitudinal study of the Australian bushfires. Disaster Prevention and Management, 22 (2), 172-181. Retrieved from http://www.emeraldinsight.com/journals.htm?articleid=17087174\&show=abstract $\quad$ doi: 10.1108/09653561311325316 
Chang, Y., Wilkinson, S., Brunsdon, D., Seville, E., \& Potangaroa, R. (2011) An integrated approach: managing resources for post-disaster reconstruction. Disasters, 35 (4), 739-765. Retrieved from http://dx.doi.org/10.1111/j.1467-7717.2011.01240.x doi:10.1111/j.14677717.2011.01240.x

Chang, Y., Wilkinson, S., Potangaroa, R., \& Seville, E. (2010, September) Resources and capacity: Lessons learned from post-disaster reconstruction resourcing in Indonesia, China and Australia. Paper presented at The 2010 Construction, Building and Real Estate Research Conference of the Royal Institution of Chartered Surveyors, Paris. Retrieved from http://hdl.handle.net/10652/1565

Chang, Y., Wilkinson, S., Potangaroa, R., \& Seville, E. (2012) Managing resources in disaster recovery projects. Engineering, Construction and Architectural Management, 19 (5), 557-580. doi:10.1108/09699981211259621

Chang, Y., Wilkinson, S., Seville, E., \& Potangaroa, R. (2012) Changes in resource need for post-disaster reconstruction: a longitudinal study in China. Building Research \& Information, 40 (3), 327-336. Retrieved from http://dx.doi.org/10.1080/09613218.2012.684867 doi:10.1080/09613218.2012.684867

Chang, Y., Wilkinson, S., Seville, E., \& Regan, P. (2010) Resourcing for a resilient postdisaster reconstruction environment. International Journal of Disaster Resilience in the Built Environment, 1 (1), 65-83. Retrieved from ABI/INFORM Global; ProQuest Central. Retrieved from $\quad$ http://www.emeraldinsight.com/journals.htm?articleid=1845975 $\quad$ doi: $10.1108 / 17595901011026481$

Chartered Institute of Building (2013) Australasia. Retrieved 2013, September 20, from http://www.ciob.org/near-you/australasia-0

Commonwealth of Australia (2011) National Strategy for Disaster Resilience. Retrieved May 23, 2013, from http://www.em.gov.au/Documents/1National\%20Strategy\%20for\%20Disaster\%20Resilience \%20-\%20pdf.PDF

Construction in focus (2013) Australian Institute of Building. Retrieved 2013, September 23, from http://www.constructioninfocus.com.au/index.php/2011/09/26/australian-buildinginstitute/

Hindustan Construction Company (n.d.) Disaster Relief. Retrieved April 13 2013, 2013from http://www.hccindia.com/four pillars.php?page=corporate stewardship\&id=0

Jim O'Sullivan, \& The Consultancy Bureau Pty Ltd. (2009) A Review Of Disaster Management Legislation And Policy In Queensland. Retrieved 2013, 11 May, from http://www.emergency.qld.gov.au/publications/pdf/consultants\%20dm\%20report\%20final.pdf

Le Masurier, J., Rotimi, J. O., \& Wilkinson, S. (2006) A comparison between routine construction and post-disaster reconstruction with case studies from New Zealand. In 22nd ARCOM Conference on Current advances in construction management research, pp. 4-6.

Lloyd-Jones, T. (2006) Mind the Gap! Post-disaster reconstruction and the transition from humanitarian relief. Retrieved from http://www.preventionweb.net/english/professional/publications/v.php?id=9080

Lorch, R. (2005) What lessons must be learned from the tsunami? Building Research \& Information, 33 (3), 209-211. Retrieved from http://dx.doi.org/10.1080/09613210500070219 doi:10.1080/09613210500070219

Norman, S. (2006) New Zealand's holistic framework for disaster recovery. The Australian Journal of Emergency Management, 21 (4), 16-20. Retrieved from http://www.em.gov.au/Documents/New+Zealand's+holistic+framework.pdf 
Petrovic-Lazarevic, S. (2008) The development of corporate social responsibility in the Australian construction industry. Construction Management \& Economics, 26 (2), 93-101. doi:10.1080/01446190701819079

Queensland Government (2011a) Rebuilding a stronger, more resilient Queensland. Retrieved 29 March 2013, from http://qldreconstruction.org.au/publications-guides/resiliencerebuilding-guidelines/rebuilding-astronger-more-resilient-queensland

Queensland Government (2011b) Resources for Reconstruction. Retrieved 29 March 2013, from http://www.qldreconstruction.org.au/publications-guides/reconstruction-plans

Queensland Reconsruciton Authority (2013) Queensland 2013 Flood Recovery Plan. Retrieved August 31, 2013, from http://qldreconstruction.org.au/publicationsguides/reconstruction-plans/queensland-flood-recovery-program-2013

Queensland Reconstruction Authority (2013) Strategic Plan 2013-14. Retrieved 2013, 7 October, from http://qldreconstruction.org.au/u/lib/cms2/Queensland-ReconstructionAuthority-Strategic-Plan-2013-14.pdf

Queensland State Disaster Management Group (2010) Disaster Management Strategic Policy Framework. Retrieved 2013, May 23, from http://disaster.qld.gov.au/Disaster\%20Resources/Documents/Disaster Management Strate gic Policy Framework.pdf

R. Haigh, D. Amaratunga, \& Kerimanginaye, K. (2006) An Exploration of the Construction Industry's Role in Disaster Preparedness, Response and Recovery. In Annual Research Conference of the Royal Institute of Chartered Surveyors RICS.

Rotimi, J. O., Wilkinson, S., \& Myburgh, D. (2011) Legislation for Effective Post-Disaster Reconstruction: Cases from New Zealand. In Post-Disaster Reconstruction of the Built Environment (pp. 151-174): Wiley-Blackwell.

Royal Institute of Chartered surveyors (2013) Members. Retrieved 2013, September 20, from http://www.rics.org/au/find-a-member/?sd=y\&cc=AU\&fn=\&ln=\&ct=

Sadiqi "Wardak", Z., Coffey, V., \& Trigunarsyah, B. (2012) Rebuilding housing after a disaster : factors for failure. Paper presented at Proceedings of 8th Annual International Conference of the International Institute for Infrastructure, Renewal and Reconstruction (IIIRR), Kumamoto, Japan. Retrieved from http://eprints.qut.edu.au/49862/

Siriwardena, M., Malalgoda, C., Thayaparan, M., Amaratunga, D., \& Keraminiyage, K. (2013) Disaster resilient built environment: role of lifelong learning and the implications for higher education. International Journal of Strategic Property Management, 17(2), 174-187. Retrieved from http://dx.doi.org/10.3846/1648715X.2013.806373 doi:10.3846/1648715x.2013.806373

Town Planning and Urban Design Collaborative (2011) Disaster Response: Planning and Rebuilding toolkit. Retrieved March 29, 2013, from http://msucares.com/pubs/publications/p2677.pdf

United Nations Office for Disaster Risk Reduction (UNISDR) (2007) Hyogo Framework for Action 2005-2015: Building the Resilience of Nations and Communities to Disasters. Retrieved April 13, 2013, from http://www.unisdr.org/we/inform/publications/1037

University of Oregon - Partnership for Disaster Resilience (2007) Post-Disaster Recovery Planning Forum: How-To Guide. Retrieved 2013, May 23, from http://nthmp.tsunami.gov/Minutes/oct-nov07/post-disaster recovery planning forum uocsc-2.pdf

Wang, J.-J. (2012) Integrated model combined land-use planning and disaster management: The structure, context and contents. Disaster Prevention and Management, 21 (1), 110-123. Retrieved

from

Stringfellow, P (2014) 'Construction contractors involvement in disaster management planning', Australasian Journal of Construction Economics and Building, 14 (2) 120-132 
http://www.emeraldinsight.com/journals.htm?articleid=17015566\&show=abstract

doi: 10.1108/09653561211202746

World Economic Forum (2011) A vision for managing natural disaster risk. Retrieved 2013, April

13 ,

from

http://www3.weforum.org/docs/WEF VisionManagingNaturalDisaster Proposal 2011.pdf

World Economic Forum (2012) Engineering \& Construction Disaster Resource Partnership.

Yan, C., Wilkinson, S., Potangaroa, R., \& Seville, E. (2011) Identifying factors affecting resource availability for post-disaster reconstruction: a case study in China. [Article]. Construction Management \& Economics, 29 (1), 37-48. Retrieved from http://gateway.library.qut.edu.au/login?url=http://search.ebscohost.com/login.aspx?direct=tru $\underline{\mathrm{e} \& \mathrm{db}=\mathrm{bsh} \& A \mathrm{~N}=57658034 \& \text { site=ehost-live }}$ doi:10.1080/01446193.2010.521761 